\title{
Effects of Coir Fibers on Workability and Strength Properties of Concrete
}

\author{
Gulmir Khan, SAHITO \\ Water and Power development Authority, WAPDA \\ gulmirsahito@yahoo.com \\ Ghulam Shabir, SOLANGI \\ Assistant Professor, Department of Civil Engineering, MUET, SZAB Campus Khairpur \\ solangi_shabir@yahoo.com \\ Manthar Ali, KEERIO \\ Department of Civil Engineering, QUEST, campus Larkana, Pakistan \\ mantharali99@quest.edu.pk
}

\begin{abstract}
This study aimed toward analyzing length and content of coir fiber on workability and strength of concrete. For this purpose, different fractions of coir fibers of length as $10 \mathrm{~mm}, 20 \mathrm{~mm}$ and $30 \mathrm{~mm}$ are used with varying proportions as $0.15 \%, 20 \%, 0.25 \%, 0.3 \%$ and $0.35 \%$ by the volume of concrete. One mix of control concrete and 15 mixes of concrete with inclusion of cot fibers were prepared. The experiments were conducted to check the workability, compressive and tensile strength of concrete. It was observed from conducted research, that the workability is decreased with increasing the content of coir fibers. On the basis of conducted research, the inclusion of $0.25 \%$ of coir fibers of length $20 \mathrm{~mm}$ is optimum. With inclusion of $0.25 \%$ of coir fibers of length $20 \mathrm{~mm}$, compressive and tensile strength is improved as compared to control mix.
\end{abstract}

\section{Keywords}

Coir Fibers, Workability, Compressive And Tensile Strength Of Concrete

\section{Introduction}

In the The concrete possesses less tensile strength less ductile which is due to presence of unsoundness and low robustness. The tensile strength and ductility of concrete can be increased by adding the natural artificial fibers [1],[2], [3], [4]. The coir fibers are natural available material like hair in coconut trees [5]. The inclusion of fibers of fibers in concrete is to improve the tensile strength which reduce the tensile cracks of composite material [6]. Coir fiber is used as reinforcement in concrete of highest toughness than the other natural fibers [7], [8]. Coir fibers are strong in tensile strength with low thermal conductivity and bulk density [9]. The coir fibers are of very low cost and its dispose off method is costly [10]. The inclusion of fiber in concrete able to absorb tension force when fibers are used as reinforcement [11], [12]. Coconut fibers are available in huge quantities in Nigeria, Asia, Africa and other regions of the world. 500,000 tons coir fibers are produced from 12 million coconut trees in world every year [13], [14], [15].

Concrete has low tensile strength only $10 \%$ of its compressive strength [16]. Due to low tensile strength of conventional concrete, microcracks develop because of drying shrinkage and other volume changes in concrete [17]. To improve the strength properties especially tensile strength, in this study Coir Fibers are included in concrete.

\section{Materials and Research Methodology}

2.1 Materials

2.1.1 Cement

Lucky, OPC is used in experimental work.

\subsubsection{Aggregate}

Bhoalri sand passed from $4.75 \mathrm{~mm}$ sieve is used in this research as shown in Figure 3.2 


\subsubsection{Coarse Aggregate}

Crushed aggregates maximum size of $19 \mathrm{~mm}$ is used. These aggregates were washed properly to use in concrete

\subsubsection{Aggregate}

10, 20 and $30 \mathrm{~mm}$ length of coir fibers are used in this study. 2

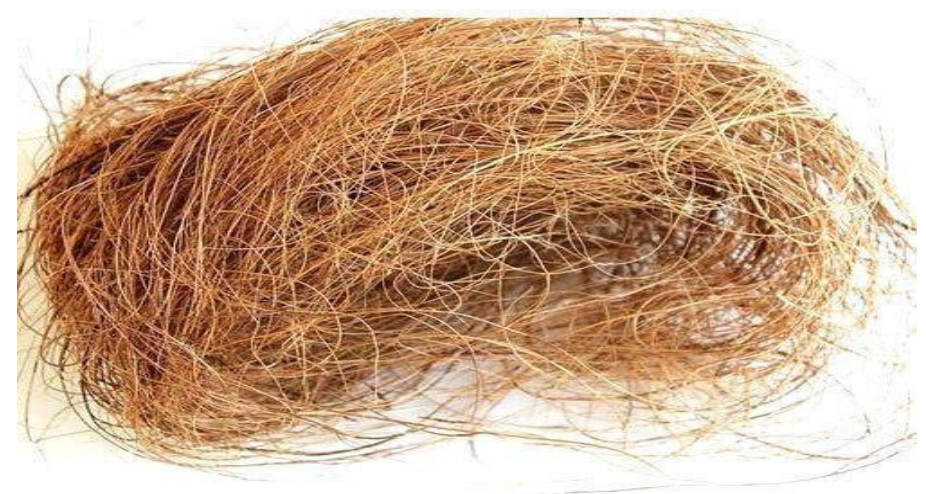

Figure 1 : Coir fibers

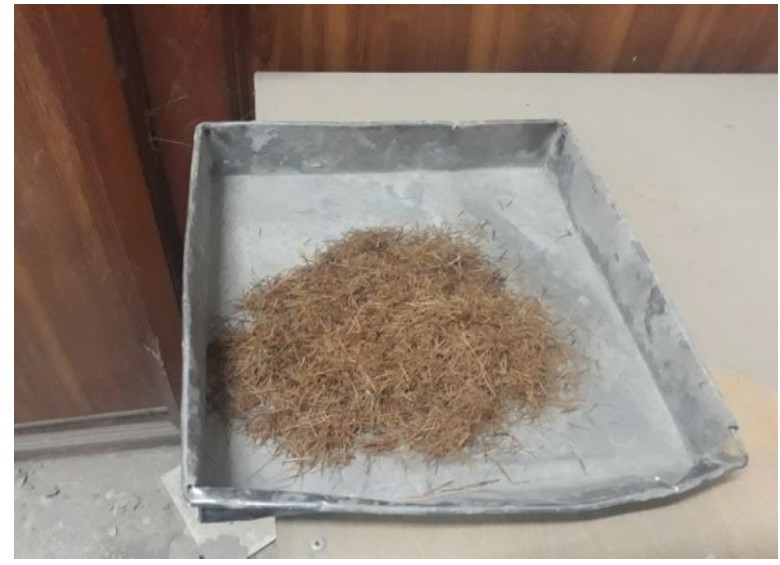

Figure 2 : Coir fibers in equal length

\subsubsection{Super plasticizer (HRWR) Aggregate}

A poly-carboxylic ether EN934-2:2000 based super plasticizer commercially named as Master Polyheed 993 from BASF Chemicals Karachi.

\subsection{Mix proportioning of concrete}

One Control concrete mix and 15 modified mixes with coir fibers are prepared. Table 1 shows the details of different ingredients of concrete. 
Table 1 : Mix of different ingredients of concrete

\begin{tabular}{|c|c|c|c|c|c|c|c|c|c|c|}
\hline $\begin{array}{l}\text { Mix } \\
\text { ID }\end{array}$ & $\begin{array}{l}\text { Cement } \\
\mathrm{Kg} / \mathrm{m}^{3}\end{array}$ & $\begin{array}{l}\text { Coir } \\
\text { fibers } \\
\mathrm{Kg} / \mathrm{m}^{3}\end{array}$ & $\begin{array}{l}\text { Length } \\
\text { fiber } \\
(\mathrm{mm})\end{array}$ & $\begin{array}{l}\text { Fiber } \\
\text { volume } \\
\text { Vf (\%) }\end{array}$ & $\begin{array}{l}\mathrm{FA} \\
\mathrm{Kg} / \mathrm{m}^{3}\end{array}$ & $\begin{array}{l}\mathrm{CA} \\
\mathrm{Kg} / \mathrm{m}^{3}\end{array}$ & $\begin{array}{l}\text { Water } \\
\mathrm{Kg} / \mathrm{m}^{3}\end{array}$ & $\mathrm{~W} / \mathrm{C}$ & $\begin{array}{l}\text { Slump } \\
(\mathrm{mm})\end{array}$ & $\begin{array}{l}\text { SP } \\
(\%)\end{array}$ \\
\hline B1 & 346 & -- & -- & -- & 692 & 1038 & 190 & 0.55 & 48 & 2 \\
\hline B2 & 346 & 2.1 & 10 & 0.15 & 692 & 1038 & 190 & 0.55 & 42 & 2.5 \\
\hline B3 & 346 & 2.8 & 10 & 0.2 & 692 & 1038 & 190 & 0.55 & 35 & 3 \\
\hline B4 & 346 & 3.5 & 10 & 0.25 & 692 & 1038 & 190 & 0.55 & 27 & 3 \\
\hline B5 & 346 & 4.2 & 10 & 0.30 & 692 & 1038 & 190 & 0.55 & 41 & 3.5 \\
\hline B6 & 346 & 4.9 & 10 & 0.35 & 692 & 1038 & 190 & 0.55 & 30 & 3.5 \\
\hline B7 & 346 & 2.1 & 20 & 0.15 & 692 & 1038 & 190 & 0.55 & 45 & 2.5 \\
\hline B8 & 346 & 2.8 & 20 & 0.2 & 692 & 1038 & 190 & 0.55 & 38 & 3 \\
\hline B9 & 346 & 3.5 & 20 & 0.25 & 692 & 1038 & 190 & 0.55 & 30 & 3 \\
\hline B10 & 346 & 4.2 & 20 & 0.30 & 692 & 1038 & 190 & 0.55 & 46 & 3.5 \\
\hline B11 & 346 & 4.9 & 20 & 0.35 & 692 & 1038 & 190 & 0.55 & 36 & 3.5 \\
\hline B12 & 346 & 2.1 & 30 & 0.15 & 692 & 1038 & 190 & 0.55 & 49 & 2.5 \\
\hline B13 & 346 & 2.8 & 30 & 0.2 & 692 & 1038 & 190 & 0.55 & 45 & 3 \\
\hline B14 & 346 & 3.5 & 30 & 0.25 & 692 & 1038 & 190 & 0.55 & 37 & 3 \\
\hline B15 & 346 & 4.2 & 30 & 0.30 & 692 & 1038 & 190 & 0.55 & 50 & 3.5 \\
\hline B16 & 346 & 4.9 & 30 & 0.35 & 692 & 1038 & 190 & 0.55 & 41 & 3.5 \\
\hline
\end{tabular}

\subsection{Method}

The workability of control and modified mixes conducted as per ASTM-C-14. The procedure for compressive and tensile strength of concrete was carried out accordance with ASTM-C-39 and ASTM-C-496 respectively

\section{Results and Discussion}

\subsection{Workability}

Figure 3 shows the comparison of results of slump for CFRC, fiber length of $10 \mathrm{~mm}$ and $20 \mathrm{~mm}$ and $30 \mathrm{~mm}$. 


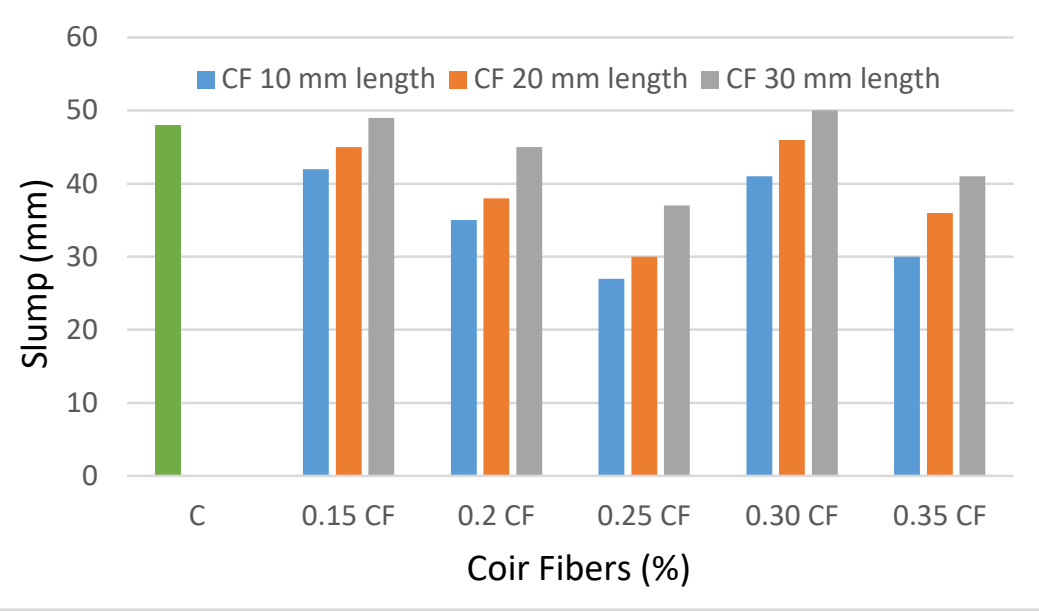

Figure 3: Comparison of workability of CFRC for CF of length $10 \mathrm{~mm}, 20 \mathrm{~mm}$ and $30 \mathrm{~mm}$ length

Figure 3 shows that with increasing the quantity of fibers workability decreases. As the length of fibers increased workability is increased. The workability of $30 \mathrm{~mm}$ length is more than of concrete prepared with $20 \mathrm{~mm}$ and $10 \mathrm{~mm}$ length. The workability of coir fiber concrete is decreased because the coir fibers are water absorbing material. To obtain the designed workability superplasticizer is used. As the quantity of coir fibers increased more quantity of super plasticizer has been used to maintain the desired workability.

\subsection{Compressive strength}

The compressive strength of control and concrete prepared with different length of coir fibers are shown in Figure 4.

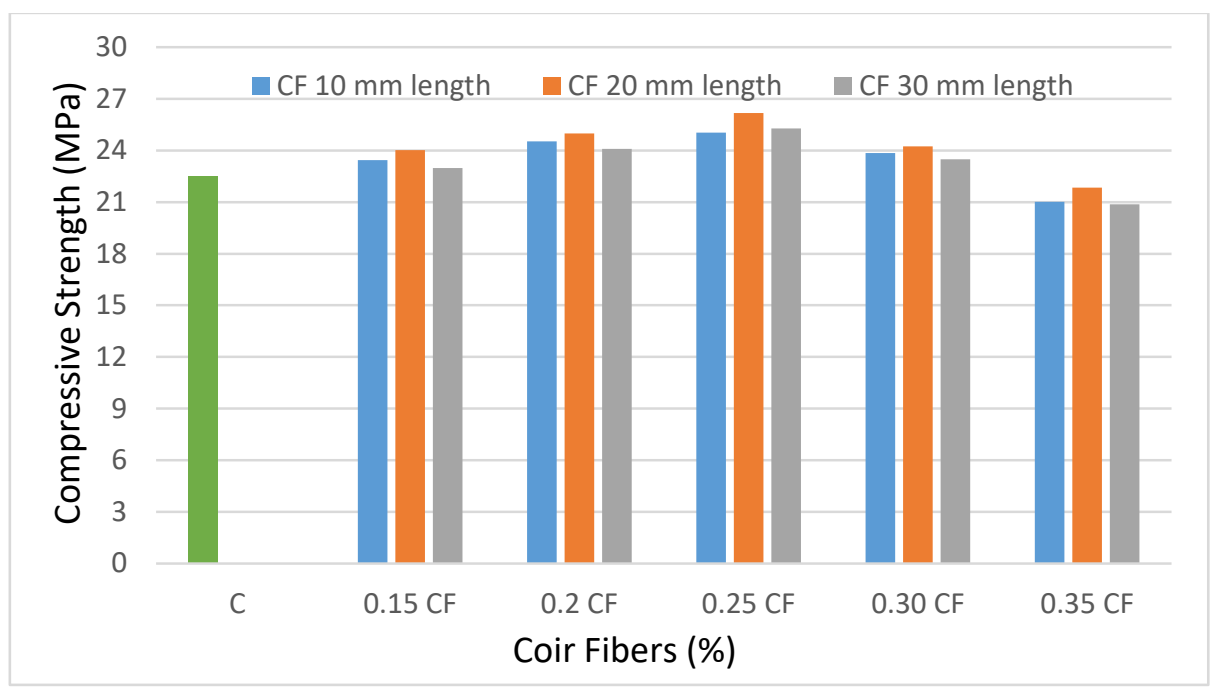

Figure 4 : Comparison of compressive strength of CFRC

It is clear form above figure 4, that Compressive strength of CFRC is increased from $0.15 \%$ to $0.25 \%$. on further inclusion of coir fibers compressive strength decreased. The maximum compressive strength of $26.17 \mathrm{MPa}$ is achieved at $0.25 \%$ addition of coir fiber of $20 \mathrm{~mm}$ length by volume fraction of concrete which is $16.31 \%$ more than control mix, further an increase in amount of coir fibers the compressive strength of CFRC did not increase. The compressive strength of $20 \mathrm{~mm}$ length of coir fibers is more than that of coir fibers length of 10 and $20 \mathrm{~mm}$ length. 


\subsection{Tensile strength}

The comparison of results of tensile strength for CFRC, fiber length of $10 \mathrm{~mm}$ and $20 \mathrm{~mm}$ and $30 \mathrm{~mm}$ length are shown in Figure 5.

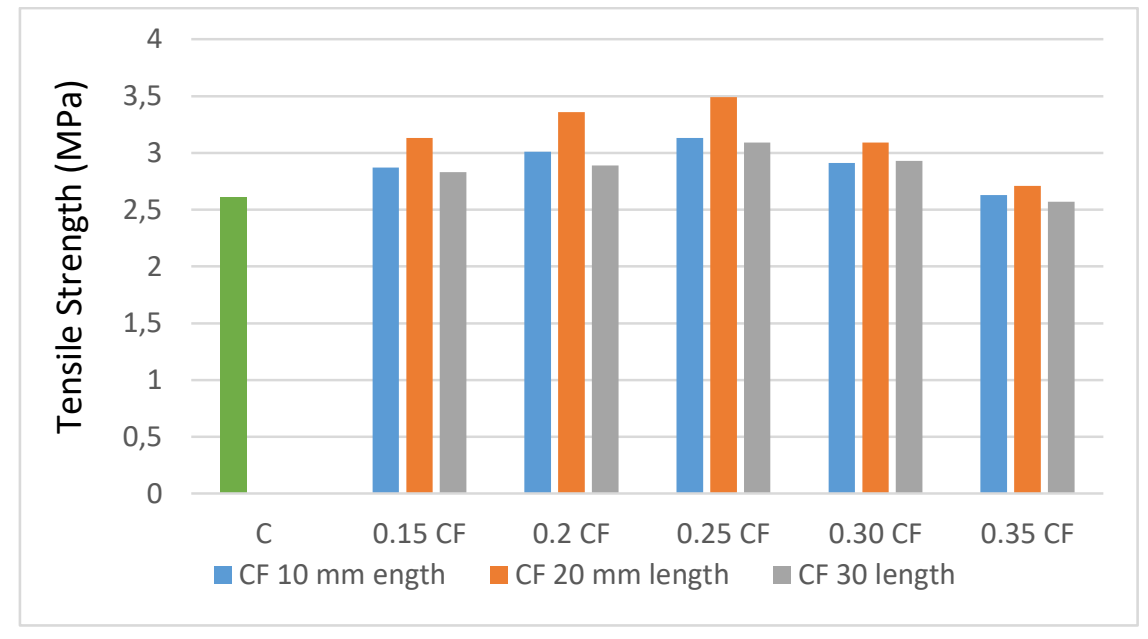

Figure 5 : Comparison of tensile strength of CFRC

It is clear form above figure that tensile strength of CFRC is increased from $0.15 \%$ to $0.25 \%$. on further inclusion of coir fibers tensile strength decreases. The maximum tensile strength of 3.49 $\mathrm{MPa}$ is achieved at $0.25 \%$ addition of coir fiber of $20 \mathrm{~mm}$ length by volume fraction of concrete which is $33.72 \%$ is more as compared to plain mix. The tensile strength of concrete with inclusion of $20 \mathrm{~mm}$ length coir fibers are more than that of coir fibers length of 10 and $20 \mathrm{~mm}$ length.

\section{Conclusion}

This On the basis of conducted research, it can be concluded that:

1) As the quantity of coir fibers are increased, the quantity of super plasticizer is increased to obtain desired workability. As the length of coir fibers increased the workability of concrete is increased.

2) Compressive strength of CFRC is improved with inclusion of coir fibers from $(0.15 \%$ to $0.25 \%$ ). The highest compressive strength of $26.17 \mathrm{MPa}$ is observed at $0.25 \%$ inclusion of coir fibers of $20 \mathrm{~mm}$ length by volume fraction of concrete which is $16.31 \%$ more than control mix.

3) Tensile strength of CFRC is improved with inclusion of coir fibers from ( $0.15 \%$ to $0.25 \%)$. The highest tensile strength of $3.49 \mathrm{MPa}$ is observed at $0.25 \%$ inclusion of coir fiber of $20 \mathrm{~mm}$ length by volume fraction of concrete which is $33.72 \%$ more than control mix, further an increase in amount of coir fibers the tensile strength of CFRC did not increase.

4) On the basis of conducted research $0.25 \%$ addition of coir fibers of length $20 \mathrm{~mm}$ by volume fraction of concrete is optimum. On $0.25 \%$ addition of coir fibers of length $20 \mathrm{~mm}$ compressive and tensile strength is improved as control mix.

\section{References}

[1] S. A. Sheikh, "A Comparative Study of Confinement Models," ACl J., vol. 79, no. 30, pp. 296306, 1986, Accessed: Jan. 14, 2021. [Online]. Available: https://www.researchgate.net/profile/Shamim_Sheikh/publication/280689189_COMPARATIVE STUDY_OF_CONFINEMENT_MODELS/links/55f3181b08ae6a34f6605157/COMPARATIVESTUDY-OF-CONFINEMENT-MODELS.pdf.

[2] J. Keer, Fibre reinforced concrete, R N Swamy. London: Surrey University Press, 1984.

[3] Y. Wang, S. Backer, and V. C. Li, "An experimental study of synthetic fibre reinforced cementitious composites," J. Mater. Sci., vol. 22, no. 12, pp. 4281-4291, Dec. 1987, doi: 10.1007/BF01132019. 
[4] A. Bentur and S. Mindess, Fibre Reinforced Cementitious Composites. London: E \& FN Spon, 1990.

[5] Z. Arshia and S. V. Murugan, "Experimental Study On Coconut Fiber In Concrete," Int. J. Prof. Eng. Stud., vol. 9, no. 3, pp. 318-323, 2017, Accessed: Jan. 14, 2021. [Online]. Available: http://www.ijpres.com/pdf36/44.pdf.

[6] I. L. Larsen and R. T. Thorstensen, "The influence of steel fibres on compressive and tensile strength of ultra high performance concrete: A review," Constr. Build. Mater., vol. 256, no. 1, p. 119459, Sep. 2020, doi: 10.1016/j.conbuildmat.2020.119459.

[7] N. I. Muhd Nadzri, S. Baharin Jamaludin, and M. Mohd Noor, "Development and properties of coconut fiber reinforced composite cement with the addition of fly ash," J. Sustain. Cem. Mater., vol. 1, no. 4, pp. 186-191, 2012, doi: 10.1080/21650373.2012.754569.

[8] M. Ali, "Use of coconut fibre reinforced concrete and coconut-fibre ropes for seismic-resistant construction," Mater. Construcción, vol. 66, no. 321, pp. 1-13, Mar. 2016, doi: 10.3989/mc.2016.01015.

[9] A. Abdullah, "Composite Cement Reinforced Coconut Fiber: Physical and Mechanical Properties and Fracture Behavior," Aust. J. Basic Appl. Sci., vol. 5, no. 7, pp. 1228-1240, 2011, Accessed: Jan. 14, 2021. [Online]. Available: https://www.researchgate.net/publication/250310862_Composite_Cement_Reinforced_Cocon ut_Fiber_Physical_and_Mechanical_Properties_and_Fracture_Behavior.

[10] N. Santhoshkumar, P. Bavatharini, M. Gokula Priya, M. Janani, and C. Jeeva, "Experimental Study On Concrete Using Coconut Shell And Coir Fiber By Partial Replacement Method," Int. J. Adv. Res. Innov., vol. 6, no. 4, pp. 1-3, 2019.

[11] J. A. Delarue, "Tensile Strength of Coconut Fiber Waste as an Organic Fiber on Concrete," Civ. Environ. Res., vol. 9, no. 11, pp. 7-11, 2017, Accessed: Jan. 14, 2021. [Online]. Available: www.iiste.org.

[12] S. Intikhab Zia, "Use Of Coconut Fiber Concrete," Int. Res. J. Eng. Technol., vol. 2, no. 6, pp. 235-237, 2015, Accessed: Jan. 14, 2021. [Online]. Available: www.irjet.net.

[13] A. W. Otunyo and N. T. Daniel, "Investigation of Properties of Concrete Stabilized with Coconut Fibre," Int. J. Civ. Eng., vol. 3, no. 11, pp. 7-12, Nov. 2016, doi: 10.14445/23488352/IJCE-V3I11P102.

[14] N. Chauhan and N. Arya, "Coconut fiber: A natural versatile material," Int. J. Chem. Stud., vol. 6, no. 6, pp. 555-561, 2018.

[15] C. Kodiarasan, K. Janarthanan, P. Dinesh, and R. Kumar, "Effect of Coconut Fibre in Concrete," J. Civ. Eng. Environ. Technol., vol. 3, no. 7, pp. 628-629, 2016, Accessed: Jan. 14, 2021. [Online]. Available: http://www.krishisanskriti.org/Publication.html.

[16] C. M. Wong, "Use of short fibres in structural concrete to enhance mechanical properties," University of Southern Queensland, 2004.

[17] S. Mindess, J. F. Young, and D. Darwin, Concrete, 2nd ed. New Jersey: Prentice Hall, 2003. 